\title{
Economics of residential gas furnaces and water heaters in US new construction market
}

\author{
Alex B. Lekov • Victor H. Franco • \\ Gabrielle Wong-Parodi • James E. McMahon • \\ Peter Chan
}

Received: 6 March 2009 / Accepted: 9 October 2009 / Published online: 30 October 2009

(C) The Author(s) 2009. This article is published with open access at Springerlink.com

\begin{abstract}
New single-family home construction represents a significant and important market for the introduction of energy-efficient gas-fired space heating and water-heating equipment. In the new construction market, the choice of furnace and water-heater type is primarily driven by first cost considerations and the availability of power vent and condensing water heaters. Few analysis have been performed to assess the economic impacts of the different combinations of space and water-heating equipment. Thus, equipment is often installed without taking into consideration the potential economic
\end{abstract}

\footnotetext{
A. B. Lekov $(\bowtie) \cdot$ V. H. Franco $\cdot$ G. Wong-Parodi

J. E. McMahon $\cdot$ P. Chan

Lawrence Berkeley National Laboratory,

One Cyclotron Road,

Berkeley, CA 94720, USA

e-mail: ABLekov@lbl.gov

URL: http://www.lbl.gov/

V. H. Franco

e-mail: VHFranco@lbl.gov

URL: http://www.lbl.gov/

G. Wong-Parodi

e-mail: GWong-Parodi@lbl.gov

URL: http://www.lbl.gov/

J. E. McMahon

e-mail: JEMcMahon@lbl.gov

URL: http://www.lbl.gov/

P. Chan

e-mail: PTChan@lbl.gov

URL: http://www.lbl.gov/
}

and energy savings of installing space and waterheating equipment combinations. In this study, we use a life-cycle cost analysis that accounts for uncertainty and variability of the analysis inputs to assess the economic benefits of gas furnace and water-heater design combinations. This study accounts not only for the equipment cost but also for the cost of installing, maintaining, repairing, and operating the equipment over its lifetime. Overall, this study, which is focused on US single-family new construction households that install gas furnaces and storage water heaters, finds that installing a condensing or power-vent water heater together with condensing furnace is the most cost-effective option for the majority of these houses. Furthermore, the findings suggest that the new construction residential market could be a target market for the large-scale introduction of a combination of condensing or power-vent water heaters with condensing furnaces.

Keywords Residential · Gas appliances · Venting · New construction · Life-cycle cost analysis · Water heating $\cdot$ Space heating

\section{Introduction}

Residential space and water heating account for 39\% of total residential primary energy consumption and 
$91 \%$ of all residential gas ${ }^{1}$ consumption in the USA (4.9 quads in 2007; US Department of Energy 2009a). A gas furnace and a gas water heater are the most common combination of space and water-heating equipment in existing single-family homes, where on average about half of all new homes (about 0.8 million from 1999 to 2007) are installed with this combination (US Department of Energy 2005; US Department of Commerce 2008).

In new single-family construction, the builder, contractor, or the architect is primarily responsible for the selection of space and water-heating equipment (Ashdown et al. 2004). Several criteria play a role in the equipment choice: lowest first cost (equipment and installation cost), familiarity with equipment by installers, code acceptability, and home buyer preference (Ghent and Keller 1999). As consumers' interest grows for equipment choices that offer significant long-term energy cost savings and reduce environmental impact, builders can find it beneficial to market their homes with more efficient equipment. In addition to consumer pressure, the federal Energy Star program and state's building codes are providing incentives and promoting more efficient equipment. Despite this, two factors contribute to the routine failure to select both more efficient furnaces and more efficient water heaters: lack of availability of condensing water heaters and lack of awareness of the economic impacts of the different combinations of space and water-heating equipment.

This study applies a life-cycle cost (LCC) analysis ${ }^{2}$ to calculate the economic advantages and disadvantages to consumers, comparing alternative gas furnace and water-heater combinations installed in new single-family homes. In the past, the US Department of Energy (DOE) has performed separate LCC analysis on residential furnaces and on water heaters (Lekov et al. 2006, 2000). However, little research has been performed to assess the economics of gas space and water-heating equipment combinations regionally and nationally. This study uses data from recent analyses by DOE that examine the energy savings and economic benefits at the household level for six selected furnace and water-heater combinations that include equipment currently available and

\footnotetext{
${ }^{1}$ Includes both natural gas and liquid petroleum gas.

${ }^{2}$ An LCC is a cost/benefit analysis over the lifetime of the equipment from a consumer perspective.
}

promoted by the Energy Star program. The study also includes a National Impact Analysis (NIA) to estimate the national energy savings and the national economic impacts from installing different gas furnace and water-heater combinations in new homes.

\section{US space heating and water-heating market characterization}

The US space heating and water-heating market differs significantly from other major markets (e.g., Europe or Japan). The US market is dominated by airdistribution systems and storage type water heaters, whereas other major markets are dominated by hydronic and heat pump systems.

\section{Space heating}

Central heating systems (air distribution and hydronics) in the USA account for $82 \%$ of residential heating equipment stock in 2001: $92 \%$ of singlefamily households built from 1980 to 2001 (US Department of Energy 2001) and 98\% of all singlefamily new construction built during 1997-2007 (US Department of Commerce 2008). Most of the remaining heating systems are direct heating equipment (room heaters, wall furnaces, fireplaces, etc.). The US central space heating market is dominated by forced air furnaces ( $85 \%$ of the stock and $97 \%$ of all singlefamily new constructions built during 1997-2007), while hydronics accounts for a smaller fraction $(15 \%$ of stock and 3\% of all single-family new construction built during 1997-2007). Table 1 shows the fraction of heating systems in single-family households by fuel type. These heating systems show significant regional differences. For example, based on US Census Regions (US Department of Commerce 2009), almost all hydronic systems are located in the northeastern US (census region 1), while electric heating equipment dominates the southern US (census region 3; see Table 1).

\section{Water heating}

The current stock of residential water-heating equipment is almost entirely storage water heaters (US Department of Energy 2001). The rest of the stock (about 1\%) includes all other water-heating catego- 
Table 1 US space heating market for single-family households (built from 1980 to 2001)

Source: RECS 2001 Survey

DHE direct heating equipment

${ }^{\mathrm{a}}$ Electric resistance and heat pumps

${ }^{\mathrm{b}}$ Other includes solar, wood, and no heating

Table 2 US Water heating market for single-family households (built after 1980)

Source: RECS 2001 Survey

\begin{tabular}{lllllll}
\hline $\begin{array}{l}\text { Heating } \\
\text { system types }\end{array}$ & Fuel & $\begin{array}{l}\text { Region 1 } \\
\text { (Northeast, \%) }\end{array}$ & $\begin{array}{l}\text { Region 2 } \\
\text { (Midwest, \%) }\end{array}$ & $\begin{array}{l}\text { Region 3 } \\
\text { (South, \%) }\end{array}$ & $\begin{array}{l}\text { Region 4 } \\
\text { (West, \%) }\end{array}$ & $\begin{array}{l}\text { National } \\
\text { (\%) }\end{array}$ \\
\hline Central air & Gas & 45 & 91 & 45 & 71 & 59 \\
& Electricity & 13 & 6 & 48 & 15 & 29 \\
& Oil & 8 & 0 & 0 & 0 & 1 \\
& Other & 3 & 0 & 0 & 1 & 0 \\
Hydronics & Gas & 5 & 0 & 0 & 1 & 1 \\
& Oil & 12 & 0 & 0 & 0 & 1 \\
& Electricity & 9 & 2 & 2 & 5 & 3 \\
& Gas & 0 & 0 & 3 & 2 & 2 \\
& Oil & 2 & 0 & 0 & 0 & 0 \\
\hline
\end{tabular}

\begin{tabular}{llllll}
\hline Fuel & $\begin{array}{l}\text { Region 1 } \\
\text { (Northeast, \%) }\end{array}$ & $\begin{array}{l}\text { Region 2 } \\
\text { (Midwest, \%) }\end{array}$ & $\begin{array}{l}\text { Region 3 } \\
\text { (South, \%) }\end{array}$ & $\begin{array}{l}\text { Region 4 } \\
\text { (West, \%) }\end{array}$ & National \\
\hline Gas & 48 & 81 & 46 & 80 & 60 \\
Electric & 34 & 19 & 54 & 19 & 38 \\
Oil & 10 & 0 & 0 & 0 & 1 \\
Combination/other & 8 & 0 & 0 & 0 & 1 \\
\hline
\end{tabular}

ries: tankless water heaters, combined space heating and water-heating appliances, ${ }^{3}$ solar water heating, district heating, and others. As shown in Table 2, storage water heaters in single-family households built after 1980 are about $60 \%$ gas-fired, $38 \%$ electric, $1 \%$ fuel oil, and $1 \%$ combination or other. ${ }^{4}$ Regionally, gas-fired water heating is dominant in all regions except in the South.

Availability of natural gas is a major driver in the selection of the heating and water-heating equipment. Newly constructed homes with natural gas access in almost all cases are equipped with gas-fired furnaces and water heaters. Regionally the gas households are mostly in the Northern and Western parts of USA. As shown in Fig. 1, for single-family houses built after

\footnotetext{
$\overline{{ }^{3} \text { Combined space heating and water heating appliances are }}$ integrated units that provide both space heating and domestic hot water and are not related to the furnace/water heater combinations evaluated in this study.

${ }^{4}$ Water heater fuel types in the single-family market segment are about the same as the national.
}

1980, the dominant combination of water heating and space heating is a gas furnace with a gas water heater (53\%) followed by an electric furnace or heat pump and electric water heater (26\%; US Department of Energy 2001).

This paper focuses on households that have both a gas furnace and a gas storage water heater. This market is projected to maintain its dominance into the future (US Department of Energy 2009a). Thus, new single-family construction represents a significant and important market for the introduction of higher energy-efficient gas space heating and water-heating technologies.

\section{US gas space heating and gas water-heating technology characterization}

Gas furnaces and water heaters are often distinguished by whether they use condensing or non-condensing technology. Gas non-condensing water heaters can be further distinguished between natural draft and power-vent technologies. 


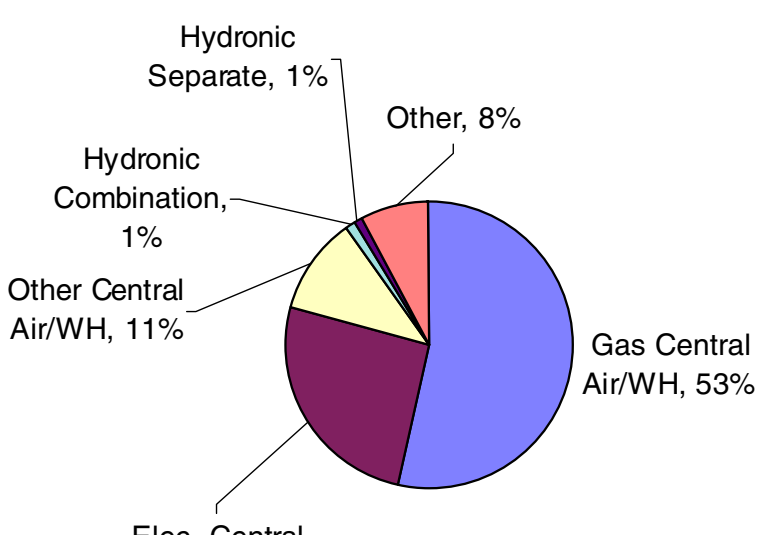

Elec. Central

Air/WH, 26\%

Fig. 1 US space heating and water-heating market for singlefamily households (built from 1980 to 2001, RECS 2001)

A typical non-condensing gas furnace has an efficiency rating of about $80 \%$ annual fuel utilization efficiency (AFUE), while a condensing furnace has an efficiency rating at or above $90 \%$ AFUE. In 2007, the most common furnace installed for replacement and in new construction ${ }^{5}$ was a non-condensing gas furnace (approximately 63\%; Air-Conditioning, Heating, and Refrigeration Institute 2008a).

The efficiency of water heaters, depending on the rated volume and other design considerations, ranges from 0.50 to 0.62 energy factor (EF) for non-condensing natural draft, from 0.60 to $0.70 \mathrm{EF}$ for non-condensing power vent, and above $0.75 \mathrm{EF}$ for condensing water heaters. In 2007, nearly all gas water heaters installed are non-condensing, with approximately 98\% natural draft and 2\% power-vent models (AirConditioning Heating and Refrigeration Institute 2008b). There are currently no shipments of residential condensing water heaters, ${ }^{6}$ but there are prototype models available, and condensing water heaters are included in the current Energy Star program (Energy Star 2008).

The electricity and venting installation requirements are different for the various furnace and water-heater designs. Condensing and non-condensing furnaces as

\footnotetext{
${ }^{5}$ Data on the share in new construction only are not available. 6 There are some "non-residential" condensing models that are being used in residential applications (e.g., A.O. Smith's Vertex models).
}

well as non-condensing power-vent water heaters and condensing water heaters require electricity to operate, while non-condensing natural-draft water heaters usually do not. Also, non-condensing natural-draft equipment is typically vented vertically through the roof, while condensing and non-condensing power-vent equipment is vented horizontally through the wall.

Figure 2 illustrates typical venting configurations. Identifying venting configurations is important because the venting system represents a significant fraction of the total installed cost and differs significantly for different furnace and water-heater combinations. Configuration $\mathrm{D}$ is the least expensive, since it uses plastic venting materials (compared to more expensive steel venting materials required in noncondensing furnaces and non-condensing natural-draft water heaters) and shorter vent lengths. Configuration A uses a single vent system for both appliances. Config-


Fig. 2 Four gas furnace and gas water-heater venting configurations: a gas furnace and water heater vented through the roof, $\mathbf{b}$ gas furnace vented through the roof and gas water heater vented through the sidewall, $\mathbf{c}$ gas furnace vented through the sidewall and gas water heater vented through the roof, and $\mathbf{d}$ gas furnace and gas water heater vented through the sidewall 


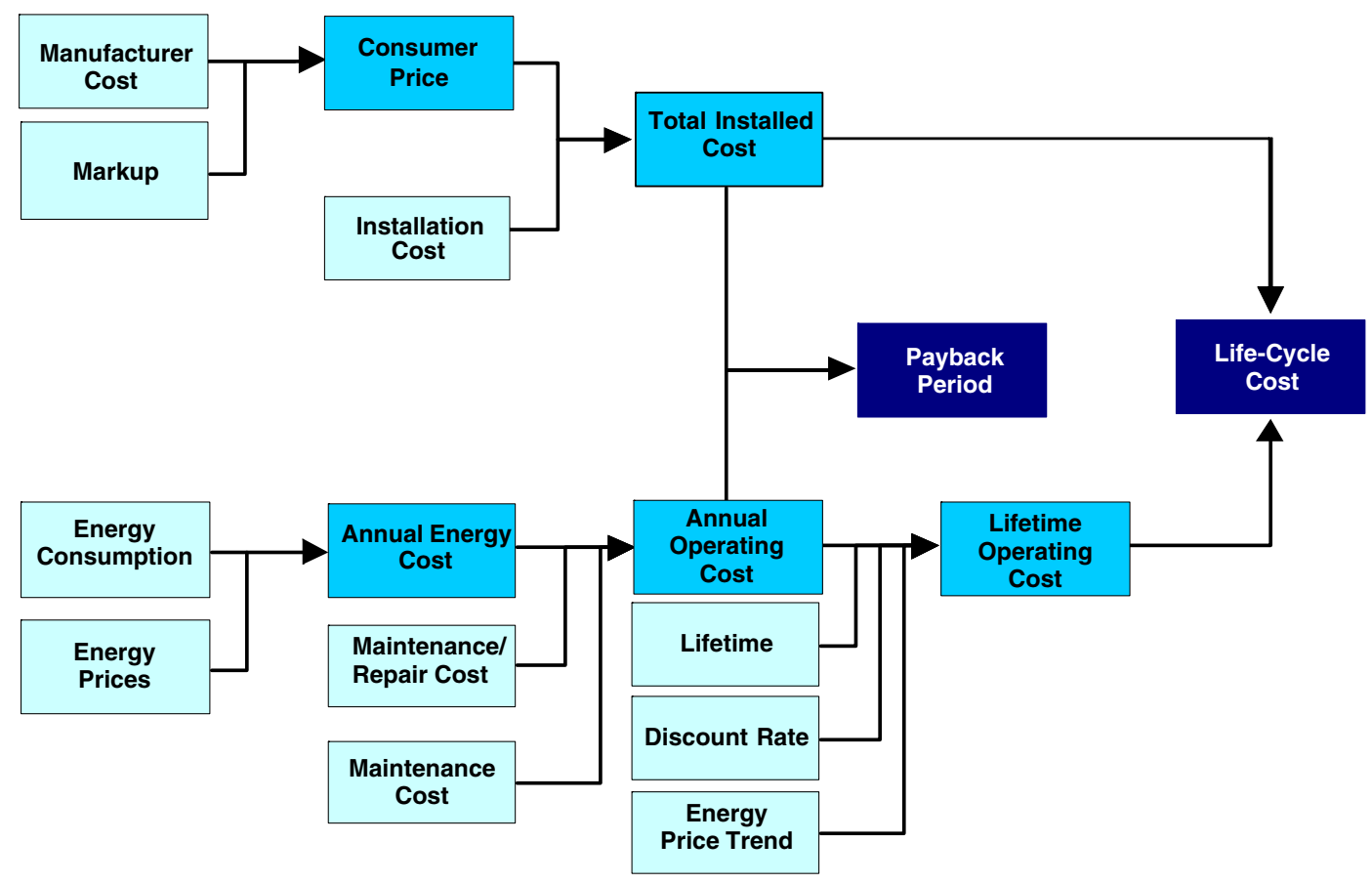

Fig. 3 Life-cycle cost analysis flowchart

urations $\mathrm{B}$ and $\mathrm{C}$ are the most expensive because of the need to apply two different venting types.

\section{Methodology}

This study assessed the energy savings and economics of the elected water-heater and furnace configurations installed in new homes. The LCC analysis addressed both the cost of buying and installing a furnace or water heater, and the operating costs summed over the lifetime of the equipment, discounted to the present. Figure 3 shows the LCC analysis components. The lightercolored boxes represent the required inputs, the darkercolored boxes represent the values calculated by these inputs, and the darkest colored boxes show the analysis results. The total installed cost is the sum of the price to the consumer of the equipment and the cost to install the equipment. The operating cost takes in account the energy consumption of the furnace and the water heater and the price of energy as well as the repair and maintenance costs. The total installed cost and the operating cost are used to calculate the payback periods and the life-cycle cost of each of the selected waterheater and furnace options.

Table 3 Gas furnace and gas water-heater options

\begin{tabular}{llll}
\hline Option & Furnace type & Gas water-heater type (EF at 40 gallon rated volume ${ }^{\mathrm{a}}$ ) & Venting configurations \\
\hline 1 & Non-condensing $(80 \%)$ & Non-condensing natural draft $(0.59)$ & Configuration a \\
2 & & Non-condensing power vent $(0.64)$ & Configuration b \\
3 & & Condensing $\left(0.80^{\mathrm{a}}\right)$ & Configuration c \\
4 & Condensing $(90 \%)$ & Non-condensing natural draft $(0.59)$ & Configuration d \\
6 & & Non-condensing power vent $(0.64)$ & \\
\hline
\end{tabular}

\footnotetext{
${ }^{\text {a }}$ Efficiency at 40-gal capacity tank. Efficiency varies with capacity

${ }^{\mathrm{b}}$ Efficiency based on current Energy Star efficiency levels
} 
Table 4 New construction households by region

\begin{tabular}{|c|c|c|c|c|c|}
\hline \multirow[t]{2}{*}{ Region labels } & \multirow[t]{2}{*}{ Census region } & \multirow[t]{2}{*}{ HDD criteria } & \multicolumn{2}{|c|}{$\begin{array}{l}\text { Average number of single-family } \\
\text { homes built with a gas furnace in } \\
1999-2007^{\text {a }}\end{array}$} & \multirow[t]{2}{*}{ Regional weights in national analysis (\%) } \\
\hline & & & In thousands per year & $\%$ & \\
\hline Region 1 & Northeast & All & 69.5 & 8.0 & 8.0 \\
\hline Region 2 & Midwest & All & 231.4 & 26.5 & 26.5 \\
\hline Region 3-cold & South & $>3,000$ & 278.8 & 31.9 & 20.4 \\
\hline Region 3-warm & & $<3,000$ & & & 11.5 \\
\hline Region 4-cold & West & $>3,000$ & 293.6 & 33.6 & 16.3 \\
\hline Region 4-warm & & $<3,000$ & & & 17.3 \\
\hline National totals & & & 873.2 & 100.0 & 100 \\
\hline
\end{tabular}

${ }^{\mathrm{a}}$ US Department of Commerce 2008

To account for the uncertainty and variability of the inputs to the LCC analysis, we applied Monte Carlo ${ }^{7}$ simulations, with many of the variables used in the calculations (e.g., discount rate, energy prices, and equipment lifetime) represented as distributions of values and with probabilities (weighting) attached to each value (Lutz et al. 2000). The LCC analysis estimated furnace and water-heater energy consumption under field conditions for a sample of households selected from the 2001 Residential Energy Consumption Survey (RECS 2001; US Department of Energy 2001). We selected those households having both a gas water heater and a gas furnace ${ }^{8}$ and built in or after $1980 .{ }^{9}$

Table 3 shows the six gas furnace and waterheating options. These options are ordered first from non-condensing to condensing furnaces and then by increasing efficiency for water-heater design options. Overall, option 1 represents the least efficient furnace and water-heater combination, and option 6 represents the most efficient combination. The efficiency values used in the calculations were mostly based on commonly available models (US Department of

\footnotetext{
${ }^{7}$ The Monte Carlo method utilizes computational algorithms that rely on repeated random sampling to compute results. In this study, the Monte Carlo analysis is performed using Crystal Ball, add-on software to MS Excel. The results are based on 10,000 samples per Monte Carlo simulation run.

${ }^{8}$ RECS does not distinguish between households that have weatherized gas furnaces (which are not included in this analysis) and non-weatherized gas furnaces.

${ }^{9}$ This is done to get a sample of households which approximates current new construction practices and allows us to generate a sufficiently large sample (447 household records representing 11.6 million households) for the analysis.
}

Energy 2007). The fact that options 5 and 6 use venting configuration $\mathrm{D}$ is significant, since this configuration is the least expensive one.

To calculate the relative advantages and disadvantages of an option, we assessed the life-cycle cost savings and the payback period (PBP) by comparing option 1, which is the most common, to higher efficiency options (2-6). Option 1 serves as the reference to which the other options are compared.

In addition to a national LCC analysis, we performed a regional LCC analysis for the four US Census regions (US Department of Commerce 2009). The regional analysis accounts for significant energy use variations due to climate conditions (particularly for furnaces) as well as for regional differences in household characteristics, energy prices, and other variables. To account for climate differences within the regions, we divided Census regions 3 and 4 into warm and cold subregions (below and above 3,000 heating degree days (HDD)). To account for the differences in regional new construction trends, we calculated weights that represent the percentage of new single-family homes in each region (see Table 4). We assumed that these weights represent homes that are built with both a gas furnace and gas water heater, since almost all homes built with a gas furnace also have a gas water heater. The regional weights were then subdivided for regions 3 and 4 based on the number of households with gas furnace and water heater in RECS 2001.

The analysis considered the period from initial furnace and water-heater installation to the end of the lifetime of the furnace. Given the lifetime distributions for the water heater and the furnace, about $95 \%$ of the 
Fig. 4 Example of non-discounted components of life-cycle cost by year

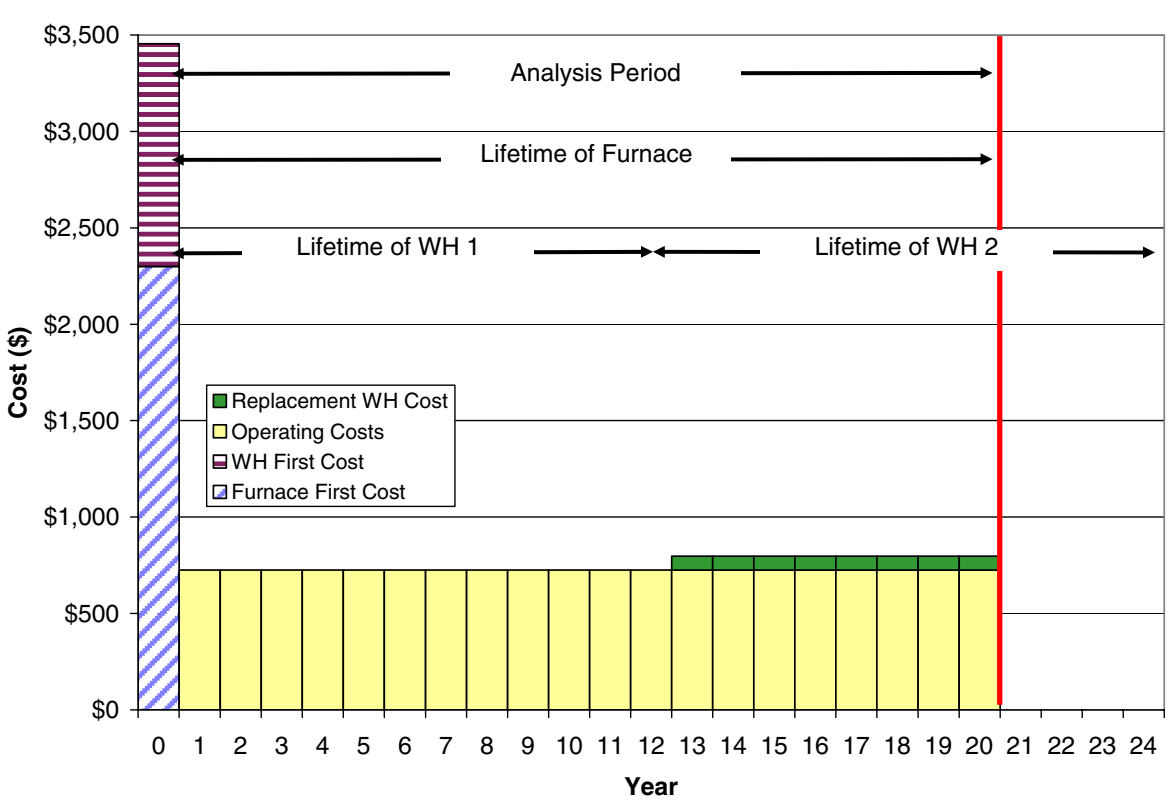

time one or more additional water heater(s) would be installed during the lifetime of the furnace. In these cases, the total installed cost of the replacement water heater was added to the operating cost as an annualized expense from the time of the replacement to the end of the furnace lifetime. Figure 4 illustrates how this calculation is included in the overall LCC analysis. The example assumes that the furnace lifetime is 20 years, and the lifetime of the first water heater and the replacement water heater is 12 years. Therefore, the annualized expense for purchase and installation of the replacement water heater is one twelfth of the total installed cost.

For the NIA analysis we calculated the net energy savings (NES) and net present value (NPV) for gas furnaces and water heaters installed in new construction and shipped over a 20-year period (20102030) using the average LCC results for the installed cost, maintenance and repair cost, and the annual energy consumption. We measured the impacts of each option against a base case, which reflects the current market share ${ }^{10}$ of the different furnace and

\footnotetext{
${ }^{10}$ There are no disaggregated shipments data for new construction homes. We estimated the market shares in current installations based on 2007 Air-Conditioning, Heating, and Refrigeration Institute total shipments data (Air-Conditioning Heating and Refrigeration Institute 2008a, b). We then adjusted these shares to reflect the fact that a higher fraction of new homes is located in South and West regions, which have a lower penetration of condensing furnaces than the nation as a whole (US Department of Energy 2007).
}

water-heater combinations. This base case reflects the fact that many builders are already installing products at higher efficiencies (especially condensing furnaces). We modeled the annual shipments in new construction by using the projected number of housing units built and the market share of gas furnaces and water heaters installed in new homes. We also accounted for the useful service life of both appliances to estimate how long they are likely to remain in stock.

\section{Analysis}

\section{LCC and PBP analysis}

The total installed cost includes the consumer price and the installation cost, which includes labor, overhead, and any miscellaneous materials and parts. The operating cost included the energy expenditures and the repair and maintenance costs as well as the total installed cost of a replacement water heater. We discuss each of these inputs below.

\section{Consumer price}

US DOE research derives the consumer price based on manufacturer cost and contractor/builder and distribu- 
Table 5 Consumer price by option for typical gas furnace and gas water heater $(2007 \$)$

\begin{tabular}{|c|c|c|c|c|c|}
\hline \multirow[t]{2}{*}{ Option } & \multicolumn{2}{|l|}{ Furnace $(75$ kBtu/h) } & \multicolumn{2}{|l|}{ Water heater (40 gal) } & \multirow[t]{2}{*}{ Total consumer price $\mathrm{e}^{\mathrm{a}}$} \\
\hline & Manufacturing costs & Average markups & Manufacturing costs & Average markups & \\
\hline 1 & $\$ 413$ & 3.37 & $\$ 160$ & 2.56 & $\$ 1,803$ \\
\hline 2 & $\$ 413$ & 3.37 & $\$ 276$ & 2.34 & $\$ 2,038$ \\
\hline 3 & $\$ 413$ & 3.37 & $\$ 425$ & 2.23 & $\$ 2,340$ \\
\hline 4 & $\$ 610$ & 3.00 & $\$ 160$ & 2.56 & $\$ 2,238$ \\
\hline 5 & $\$ 610$ & 3.00 & $\$ 276$ & 2.34 & $\$ 2,473$ \\
\hline 6 & $\$ 610$ & 3.00 & $\$ 425$ & 2.23 & $\$ 2,775$ \\
\hline
\end{tabular}

${ }^{\text {a }}$ Consumer prices in this table may not add up exactly to manufacturing cost multiplied by average markup due to rounding

Table 6 Installation costs for furnace and water-heater options (2007\$)

\begin{tabular}{|c|c|c|c|c|c|c|}
\hline \multirow[t]{2}{*}{ Option } & \multirow[t]{2}{*}{ Venting installation configuration } & \multicolumn{2}{|c|}{ Basic installation } & \multicolumn{2}{|l|}{ Venting } & \multirow[t]{2}{*}{ Total } \\
\hline & & Furnace & Water heater & Furnace & Water heater & \\
\hline 1 & Configuration A & $\$ 451$ & $\$ 340$ & $\$ 829$ & & $\$ 1,620$ \\
\hline 2 & Configuration B & $\$ 451$ & $\$ 340$ & $\$ 443$ & $\$ 777$ & $\$ 2,011$ \\
\hline 3 & Configuration B & $\$ 451$ & $\$ 347$ & $\$ 443$ & $\$ 777$ & $\$ 2,018$ \\
\hline 4 & Configuration $\mathrm{C}$ & $\$ 453$ & $\$ 340$ & $\$ 777$ & $\$ 443$ & $\$ 2,013$ \\
\hline 5 & Configuration D & $\$ 453$ & $\$ 340$ & $\$ 213$ & $\$ 213$ & $\$ 1,219$ \\
\hline 6 & Configuration D & $\$ 453$ & $\$ 347$ & $\$ 213$ & $\$ 213$ & $\$ 1,226$ \\
\hline
\end{tabular}

Table 7 Average total installed costs furnace and water-heater options (2007\$)

\section{${ }^{\text {a }}$ Consumer prices in this} table are averages over the range of furnace and waterheater capacities, not just the representative capacities in Table 5

\begin{tabular}{lllll}
\hline Option & Consumer price $^{\mathrm{a}}$ & Installation cost & Total installed cost & Incremental total installed cost \\
\hline 1 & $\$ 1,858$ & $\$ 1,620$ & $\$ 3,478$ & - \\
2 & $\$ 2,098$ & $\$ 2,011$ & $\$ 4,109$ & $\$ 631$ \\
3 & $\$ 2,397$ & $\$ 2,018$ & $\$ 4,415$ & $\$ 937$ \\
4 & $\$ 2,314$ & $\$ 2,013$ & $\$ 4,327$ & $\$ 849$ \\
5 & $\$ 2,554$ & $\$ 1,219$ & $\$ 3,773$ & $\$ 295$ \\
6 & $\$ 2,853$ & $\$ 1,226$ & $\$ 4,079$ & $\$ 601$ \\
\hline
\end{tabular}

Table 8 House heating load and hot water use by region

\begin{tabular}{|c|c|c|c|c|c|c|c|c|}
\hline & & $\begin{array}{l}\text { Region } 1 \\
\text { (Northeast) }\end{array}$ & $\begin{array}{l}\text { Region } 2 \\
\text { (Midwest) }\end{array}$ & $\begin{array}{l}\text { Region } 3 \\
\text { cold (South) }\end{array}$ & $\begin{array}{l}\text { Region } 3 \\
\text { warm (South) }\end{array}$ & $\begin{array}{l}\text { Region } 4 \\
\text { cold (West) }\end{array}$ & $\begin{array}{l}\text { Region } 4 \\
\text { warm (West) }\end{array}$ & National \\
\hline \multirow[t]{2}{*}{ House heating load, MMBtu/year } & Avg & 49.0 & 54.2 & 39.5 & 17.7 & 48.1 & 18.8 & 39.4 \\
\hline & Med & 45.7 & 51.4 & 35.3 & 14.5 & 41.6 & 13.5 & 35.6 \\
\hline \multirow[t]{2}{*}{ Hot water use, gal/day } & Avg & 40.4 & 51.5 & 53.2 & 58.5 & 53.3 & 56.1 & 52.9 \\
\hline & Med & 38.0 & 47.2 & 48.6 & 53.8 & 49.8 & 51.5 & 48.6 \\
\hline
\end{tabular}


Table 9 Gas furnace and gas water-heater component repair cost and lifetime

\begin{tabular}{|c|c|c|c|c|}
\hline & Component & $\begin{array}{l}\text { Component } \\
\text { lifetime }\end{array}$ & $\begin{array}{l}\text { Repair cost } \\
(2007 \$)\end{array}$ & $\begin{array}{l}\text { Applied } \\
\text { to option }\end{array}$ \\
\hline \multirow[t]{3}{*}{$\begin{array}{l}\text { Gas } \\
\text { furnace }\end{array}$} & $\begin{array}{l}\text { Electronic } \\
\text { ignition }\end{array}$ & 10 & $\$ 204$ & $\begin{array}{l}1,2,3 \\
4,5,6\end{array}$ \\
\hline & Blower motor & 12 & $\$ 297$ & $\begin{array}{c}1,2,3 \\
4,5,6\end{array}$ \\
\hline & Inducer motor & 15 & $\$ 297$ & $\begin{array}{r}1,2,3 \\
4,5,6\end{array}$ \\
\hline \multirow[t]{3}{*}{$\begin{array}{l}\text { Gas water } \\
\text { heater }\end{array}$} & $\begin{array}{l}\text { Pilot light } \\
\text { ignition }\end{array}$ & 10 & $\$ 162$ & 1,4 \\
\hline & $\begin{array}{c}\text { Electronic } \\
\text { ignition }\end{array}$ & 15 & $\$ 204$ & $2,3,5,6$ \\
\hline & Power vent & 15 & $\$ 297$ & $2,3,5,6$ \\
\hline
\end{tabular}

tor markups for the gas furnace and the gas water heater (US Department of Energy 2007, 2009a, b). ${ }^{11,12}$ Manufacturer costs vary by rated volume for water heaters and by heating capacity and blower size for furnaces. The incremental cost of a power-vent water heater compared to a standard water heater includes the cost of additional components (blower and electronic ignition). The manufacturer cost of a condensing water heater includes the cost of changes to the heat exchanger and the tank. The analysis used contractor/builder and distributor markups to transform the manufacturer costs into a consumer price. The markup methodology assumes lower overall markup for higher efficiency equipment (condensing furnaces and water heaters and power-vent water heaters), because some distribution costs do not increase with increased efficiency. ${ }^{13}$ Table 5 shows the manufacturer costs and the applicable markups for furnace and water heater at representative capacities as used to derive the consumer prices used in the LCC analysis.

\footnotetext{
${ }^{11}$ DOE's research used a reverse-engineering approach to obtain the manufacturer's costs.

12 The consumer prices (particularly for residential furnaces as well as for condensing water heaters) are not commonly available. Space heating and water heating equipment are sold through several different distribution channels that have different price structures. To avoid these uncertainties we derived the consumer prices using the manufacturer cost and markup multipliers.

${ }^{13}$ The lower overall markup cost for higher efficiency equipment is explained in the US DOE 2006 Furnace and Boiler Rulemaking TSD (US Department of Energy 2007).
}

\section{Installation cost}

The installation cost for each of the options is in Table 6. The installation cost values comes from US DOE research based on RSMeans cost estimates (US Department of Energy 2009b). The installation cost includes labor and materials for the gas furnace and water heater. The basic installation includes adding a gas line branch, water piping and condensate drain for water heaters and air-distribution connections and electrical components for furnaces, and the cost of locating and setting up the units. The only difference in basic installation cost between condensing and non-condensing equipment is the difference in cost of withdrawing the condensate via a horizontal plastic vent compared to withdrawing the exhaust via a vertical metal vent. We considered three different vent system installation costs: option 1 used a common vent through the roof; options 2, 3, and 4 used a combination of vertical metal vent and horizontal plastic vent; and options 5 and 6 used plastic vent. ${ }^{14}$

The total installed cost includes the consumer price and the installation costs and is presented as a distribution of values ("Appendix 2" and Fig. 12 of "Appendix 1"). Table 7 shows the average total installed costs from that distribution. The incremental total installed cost represents the difference between option 1 and each of the other options. Options 5 and 6 , which feature a condensing furnace and power vent or condensing water heater, respectively, have the lowest incremental total installed costs because their lower installation costs partially offsets the higher consumer price.

\section{Heating load and hot water use}

Energy consumption for both the furnace and the water heater comes from calculations that used DOE test procedure parameters (see "Appendix 3"; Lutz et al. 1999, 2004). The house heating load (for furnaces) and the hot water use (for water heaters) used in the calculations vary for each sample household. Table 8 shows the house heating load and hot water use average and median values for the

\footnotetext{
${ }^{14}$ Options 5 and 6 assume the equipment location is close to the wall to avoid long vent runs. In all cases, the water heater and furnace were assumed to be installed close to each other.
} 
Table 10 Average energy use and operating costs (2007\$)

${ }^{\text {a }}$ Including water-heater replacement if applicable

\begin{tabular}{llllll}
\hline Option & $\begin{array}{l}\text { Annual gas use } \\
\text { MMBtu/year }\end{array}$ & Annual elec use & $\begin{array}{l}\text { Annual maintenance/ } \\
\text { repair cost }{ }^{\mathrm{a}} \\
\$ / \text { year }\end{array}$ & $\begin{array}{l}\text { Avg operating } \\
\text { cost } \\
\$\end{array}$ & $\begin{array}{l}\text { Avg operating } \\
\text { cost savings } \\
\$\end{array}$ \\
\hline 1 & 64.89 & 433 & $\$ 178$ & $\$ 14,917$ & - \\
2 & 63.06 & 503 & $\$ 202$ & $\$ 14,802$ & $\$ 116$ \\
3 & 59.47 & 493 & $\$ 227$ & $\$ 14,195$ & $\$ 722$ \\
4 & 59.86 & 369 & $\$ 178$ & $\$ 13,869$ & $\$ 1,049$ \\
5 & 58.03 & 438 & $\$ 202$ & $\$ 13,753$ & $\$ 1,164$ \\
6 & 54.45 & 428 & $\$ 227$ & $\$ 13,146$ & $\$ 1,771$ \\
\hline
\end{tabular}

household sample by region (the resulting distribution of values is shown in Figs. 13 and 14 of “Appendix 2"). The national average hot water use (57.9 gal) is higher than the average value for gas water heaters (49.9 gal) reported in the DOE waterheater study (US Department of Energy 2005) because the household sample for new construction includes only RECS households built from 1980 to 2001 and not the entire stock. The new construction sample weights more toward warmer regions, and the number of occupants per household is higher than the national average.

\section{Operating costs}

The operating costs represent the costs paid by the consumer to operate and maintain or repair the furnace and the water heater over the lifetime of the equipment. The operating cost uses inputs from household energy consumption and energy prices. Average monthly energy prices were determined separately for the nine Census divisions and four large states based on 2006 EIA data, historical monthly EIA data, and 2006 US Census Bureau population estimates (US Department of Energy 2005, 2006a, b; US Department of Commerce 2006). The derived energy prices were matched to each individual household depending on its location. To arrive at prices in future years, we multiplied the 2006 average prices by the forecast of annual average price changes in AEO2009 (US Depart-

Table 11 Furnace and water-heater lifetime

\begin{tabular}{lccc}
\hline Product class & Minimum & Average & Maximum \\
\hline Gas water heater & 6 & 12 & 18 \\
Gas furnace & 10 & 20 & 30 \\
\hline
\end{tabular}

ment of Energy 2009a). "Appendix 1" provides more details about the energy prices used in the analysis.

The furnace maintenance cost accounts for regular maintenance, while no maintenance cost was associated with the water heaters. The analysis assumed that certain components of both furnaces and water heaters might be repaired during the lifetime of the equipment (e.g., ignition device, blower motor, and power vent; US Department of Energy 2009b). ${ }^{15}$ Table 9 lists the repair cost of key components as used in the analysis.

The operating cost accounts for the household annual energy consumption as well as for the maintenance and repair and is expressed as a distribution of values (Fig. 15 of "Appendix 2"). Table 10 shows the average energy use and operating cost for the analyzed household sample. The operating cost savings reflect the difference between option 1 and each of the other options. Option 6 has the lowest average operating cost and the highest annual fuel savings.

Condensing water heaters on average show more fuel savings than condensing furnaces. This is due to the higher efficiency difference between non-condensing and condensing water heaters (about 37\%) compared to the difference between non-condensing and condensing furnaces (about 13\%).

\section{Discount rate}

The LCC analysis discounted future operating costs to 2010 and summed them over the lifetime of the furnace. The discount rate used reflects after-tax real mortgage rates and on average equals $3.2 \%$ (US Department of Energy 2007).

\footnotetext{
${ }^{15}$ In the LCC analysis both the lifetime of the equipment and the component lifetime are presented as distributions. Therefore only households that have longer equipment lifetime encounter repair costs.
} 
Fig. 5 New construction shipments (historical from 1999 to 2007 and projected from 2008 to 2030 )

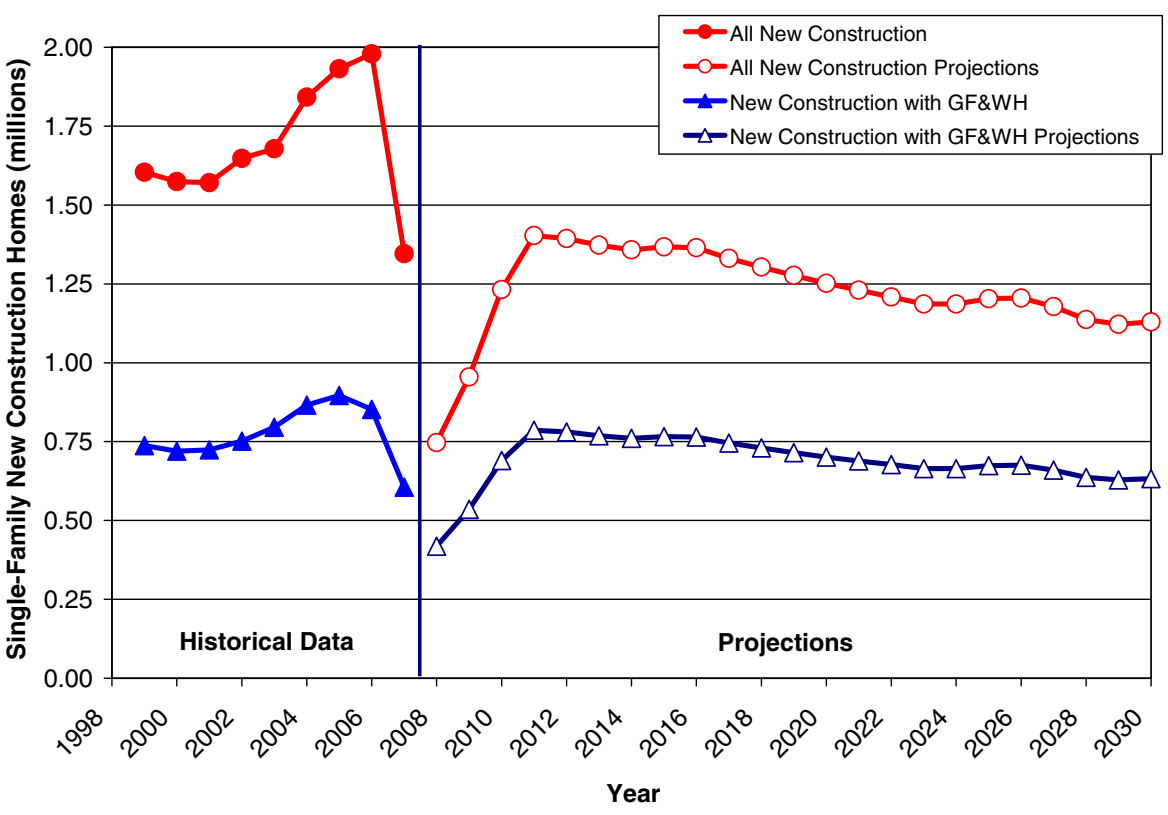

\section{Lifetime}

Lifetime estimates for furnaces and water heaters are shown in Table 11 (US Department of Energy 2007, 2008). In the analysis, lifetime is represented as a triangular probability distribution. The analysis uses the same lifetime for all furnace and water-heater designs.

National impacts analysis

The primary input parameters used in the NIA are discount rate, lifetime and energy prices along with the unit price, energy use and installation, and repair costs from the LCC analysis. Figure 5 shows the projected new construction shipments of gas furnace

Table 12 Average LCC and LCC savings (2007\$)

\begin{tabular}{lclll}
\hline Option & $\begin{array}{l}\text { Total installed } \\
\text { cost }\end{array}$ & $\begin{array}{l}\text { Operating } \\
\text { cost }\end{array}$ & $\begin{array}{l}\text { Total } \\
\text { LCC }\end{array}$ & $\begin{array}{l}\text { LCC } \\
\text { savings }\end{array}$ \\
\hline 1 & $\$ 3,478$ & $\$ 14,917$ & $\$ 18,395$ & - \\
2 & $\$ 4,109$ & $\$ 14,802$ & $\$ 18,911$ & $(\$ 516)$ \\
3 & $\$ 4,415$ & $\$ 14,195$ & $\$ 18,610$ & $(\$ 215)$ \\
4 & $\$ 4,327$ & $\$ 13,869$ & $\$ 18,196$ & $\$ 199$ \\
5 & $\$ 3,773$ & $\$ 13,753$ & $\$ 17,526$ & $\$ 869$ \\
6 & $\$ 4,079$ & $\$ 13,146$ & $\$ 17,225$ & $\$ 1,170$ \\
\hline
\end{tabular}

Negative savings within parentheses and water heaters in 2010-2030, which is based on new housing completion projections from the 2008 Annual Energy Outlook (AEO 2008; US Department of Energy 2008). The estimated average fraction of new housing completions with gas furnaces and gas water heaters is $49.5 \%$ based on US Census data (Table 2) and data from the 2005 American Housing Survey (US Department of Commerce 2005).

The NIA calculates national energy savings at the site level and then uses conversion factors from AEO 2008 to convert to primary energy use. ${ }^{16}$ NIA also includes the impact of the rebound effect (also called a take-back effect or offsetting behavior), which refers to increased energy consumption resulting from actions that increase energy efficiency and reduce consumer costs. ${ }^{17}$ To account for the rebound effect, national energy savings are reduced $10 \%$ for water heaters and $15 \%$ for furnaces (US Department of Energy 2007, 2009b).

\footnotetext{
${ }^{16}$ Site energy is the amount of heat and electricity consumed on site by a building as reflected in utility bills. Primary energy is the raw fuel that is burned to create heat and electricity, such as fuel used to generate electricity at a power plant, plus other losses in producing and transporting the fuel and electricity.

${ }^{17}$ The logic behind the rebound effect is that more energyefficient products lower the marginal cost of the end-use service relative to lower energy-efficient products so consumers take some of the energy savings back in increased comfort or service.
} 
Fig. 6 LCC impacts for US new construction households

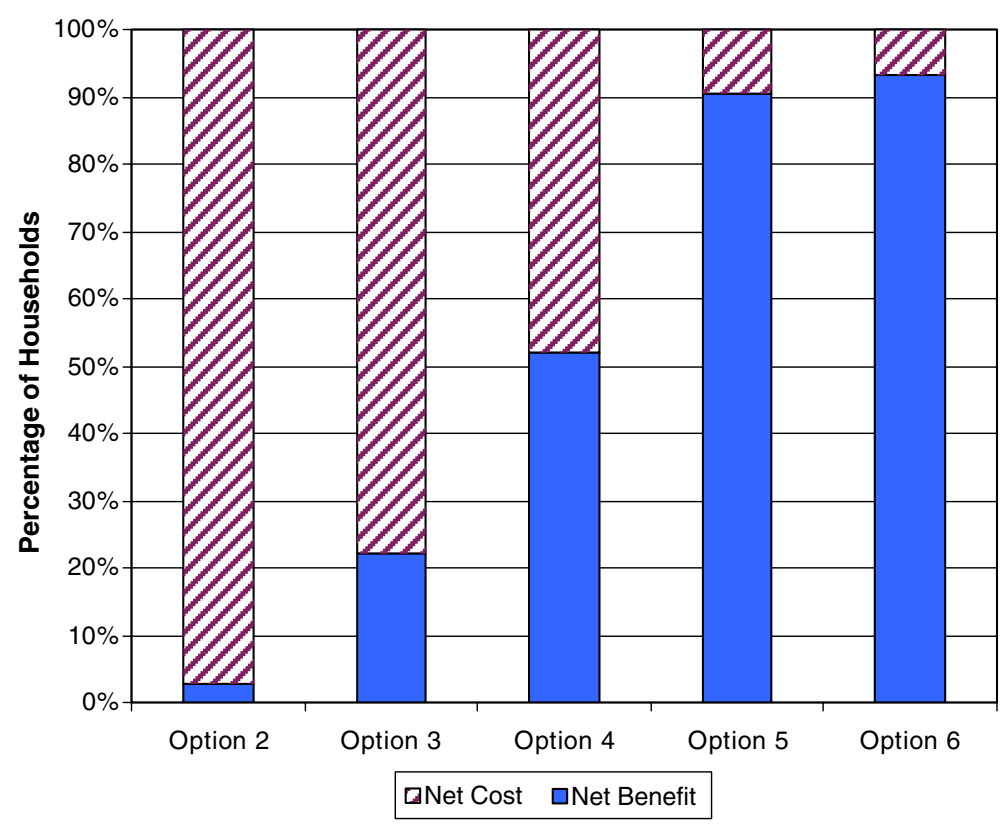

\section{Results}

Table 12 shows the average total installed cost, operating cost, total LCC, and average LCC savings for the six options (the distribution of LCC savings is in Fig. 16 of "Appendix 2"). Option 6 has the highest LCC savings $(\$ 1,170)$, followed by option 5 (\$869). Options 2 and 3 have negative LCC savings or increased costs.
Figure 6 shows the percentage of all US new construction households that would experience a positive LCC savings (net benefit) or negative LCC savings (net cost) compared to option 1 if they were to install a combination of gas furnace and water heater as in options 2-6. All options with a condensing furnace (options 4-6) have net benefits for more than half of the households (52\% for option 4, $90 \%$ for option 5 , and $93 \%$ for option 6), while
Fig. 7 Median and average household PBP

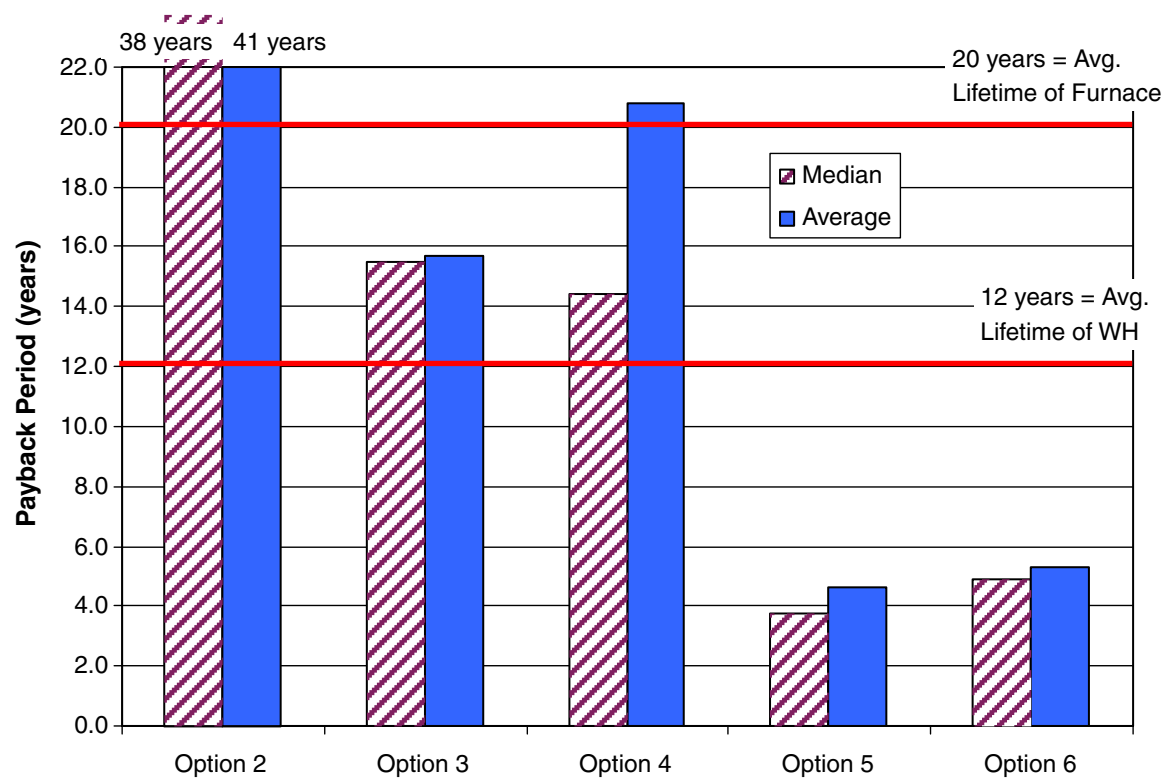


Table 13 Average LCC savings by region (2007\$)

\begin{tabular}{|c|c|c|c|c|c|c|}
\hline Option & $\begin{array}{l}\text { Region } 1 \\
\text { (Northeast) }\end{array}$ & $\begin{array}{l}\text { Region } 2 \\
\text { (Midwest) }\end{array}$ & $\begin{array}{l}\text { Region } 3 \\
\text { cold (South) }\end{array}$ & $\begin{array}{l}\text { Region } 3 \\
\text { warm (South) }\end{array}$ & $\begin{array}{l}\text { Region } 4 \\
\text { cold (West) }\end{array}$ & $\begin{array}{l}\text { Region } 4 \\
\text { warm (West) }\end{array}$ \\
\hline 1 & - & - & - & - & - & - \\
\hline 2 & $(\$ 494)$ & $(\$ 514)$ & $(\$ 472)$ & $(\$ 524)$ & $(\$ 452)$ & $(\$ 632)$ \\
\hline 3 & $(\$ 197)$ & $(\$ 241)$ & $(\$ 121)$ & $(\$ 260)$ & $\$ 10$ & $(\$ 473)$ \\
\hline 4 & $\$ 611$ & $\$ 468$ & $\$ 198$ & (\$394) & $\$ 548$ & $(\$ 323)$ \\
\hline 5 & $\$ 1,302$ & $\$ 1,140$ & $\$ 912$ & $\$ 268$ & $\$ 1,281$ & $\$ 230$ \\
\hline 6 & $\$ 1,599$ & $\$ 1,413$ & $\$ 1,263$ & $\$ 532$ & $\$ 1,743$ & $\$ 390$ \\
\hline
\end{tabular}

Values in parentheses indicate negative numbers

options 2 and 3 have net benefits for less than $50 \%$ of households (3\% for option 2 and $22 \%$ for option 3 ).

Figure 7 shows the median and average payback period relative to option 1 . Options 5 and 6 have the lowest payback periods (median payback period of 3.8 and 4.9 years, respectively). Options 3 and 4 have median paybacks of about 14-15 years, while option 2 has median and average payback beyond the lifetime of the equipment.

Table 13 shows the average LCC savings by region. The LCC savings vary by region because of the significant variations of the furnace heating load due to climate differences and regional energy prices. Option 6 shows the highest LCC savings for all regions. For regions above 3,000 HDD (regions 1, 2, and 3-cold; 4 - cold), which account for about two thirds of the new construction homes, the average LCC savings for option 6 are between \$1,263 and $\$ 1,743$. The average LCC savings drop to $\$ 390$ to $\$ 532$ for the regions below 3,000 HDD (about one third of new construction households). Option 5 is also cost-effective in all regions. In general, option 4 shows savings in cold climates, but not in warm regions. Options 2 and 3 are generally not costeffective (except option 3 in region 4 -cold).

Table 14 shows the payback period by region for all options. In general, options 6 and 5 have median payback periods less than 8 years in all regions and less than 5 years in regions above 3,000 HDD. Options 3 and 4 offer median paybacks between 10 and 16 years in regions above 3,000 HDD, but median paybacks rise in regions below 3,000 HDD to 15 to 19 for option 3 and above the lifetime for option 4. Option 2 has median and average paybacks beyond the lifetime of either equipment in all regions.

The most cost-effective option (i.e., the lowest total LCC) for each household in each region is shown in Fig. 8. Option 6 has the lowest total LCC for $83 \%$ of all households, except for region 4-warm, where this fraction is approximately $65 \%$.

Condensing water heaters, included in options 3 and 6 , are not yet available for residential storage-tank applications. Figure 9 shows the most cost-effective for each household in wach region, excluding condensing waster heaters (i.e., options 3 and 6). Option 5 , which combines condensing furnace and power-vent

Table 14 Payback period by region (years)

\begin{tabular}{|c|c|c|c|c|c|c|c|c|c|c|c|c|}
\hline \multirow[t]{2}{*}{ Option } & \multicolumn{2}{|c|}{$\begin{array}{l}\text { Region } 1 \\
\text { (Northeast) }\end{array}$} & \multicolumn{2}{|c|}{$\begin{array}{l}\text { Region } 2 \\
\text { (Midwest) }\end{array}$} & \multicolumn{2}{|c|}{$\begin{array}{l}\text { Region } 3 \text { cold } \\
\text { (West) }\end{array}$} & \multicolumn{2}{|c|}{$\begin{array}{l}\text { Region } 3 \text { warm } \\
\text { (West) }\end{array}$} & \multicolumn{2}{|c|}{$\begin{array}{l}\text { Region } 4 \text { cold } \\
\text { (South) }\end{array}$} & \multicolumn{2}{|c|}{$\begin{array}{l}\text { Region } 4 \text { warm } \\
\text { (South) }\end{array}$} \\
\hline & Avg & Med & Avg & Med & Avg & Med & Avg & Med & Avg & Med & Avg & Med \\
\hline 1 & - & - & - & - & - & - & - & - & - & - & - & - \\
\hline 2 & 34 & 34 & 39 & 39 & 34 & 33 & 35 & 42 & 32 & 33 & 64 & 63 \\
\hline 3 & 14 & 14 & 16 & 16 & 15 & 15 & 15 & 16 & 13 & 13 & 19 & 19 \\
\hline 4 & 10 & 11 & 11 & 12 & 14 & 16 & 35 & 43 & 12 & 12 & 36 & 37 \\
\hline 5 & 2.8 & 2.9 & 3.2 & 3.4 & 3.7 & 3.9 & 6.8 & 7.2 & 2.9 & 3.1 & 7.8 & 7.9 \\
\hline 6 & 4.0 & 4.0 & 4.4 & 4.5 & 4.8 & 4.8 & 6.9 & 7.0 & 3.9 & 4.0 & 7.6 & 7.7 \\
\hline
\end{tabular}


Fig. 8 Options with lowest total LCC by region

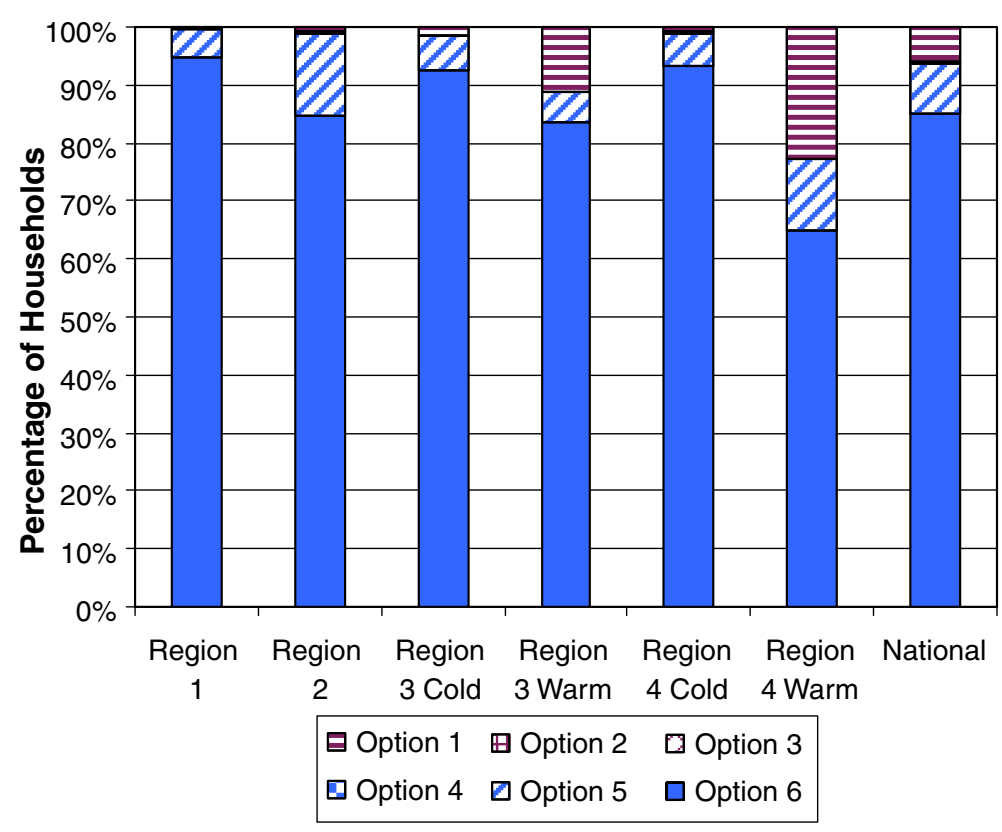

water heater, is the option with the lowest LCC for more than $90 \%$ of the households nationally and more than $95 \%$ of the households in all regions except regions 3 warm and 4-warm. Power-vent technology is readily available and currently maintains about a $2 \%$ share of the gas water-heater market.

The NES and NPV results for the six options are shown in Fig. 10. For the nation, option 6 has the highest
NES (1.5 quads) and NPV ( $\$ 8.0$ billion) over the 2010 2030 period. Option 5 also has positive NES (0.7 quads) and NPV (\$5.0 billion). Option 4 has a positive NES (0.6 quads) and NPV (\$0.1 billion). Options 2 and 3 have positive NES results, but negative NPV results. The positive NPV for options 5 and 6 reflects their lower installation cost compared to options 2, 3, and 4 and their higher operating cost savings.
Fig. 9 Options with lowest total LCC (excluding condensing water heaters)






\section{Conclusion}

For the US single-family housing market the dominant combination of water heating and space heating is a gas furnace with a gas water heater. The results for the new construction segment of the single-family market show that options 4, 5, and 6 (condensing furnace with any type of water heating) show positive LCC savings. The LCC savings are very significant for options 5 and 6 , which combine a condensing furnace with either a power-vent or condensing water heater. Over $90 \%$ of the natural-gas-using new single-family homes in the US would benefit from installing either options 5 or 6 . These two options also have the lowest average payback (3.8 years for option 5 and 4.8 years for option 6 ). In all US regions, options 5 and 6 have the highest average LCC savings and the lowest average payback.

Option 6 is the most cost-effective technology (with lowest LCC) for $83 \%$ of all US households. Option 6 also has the lowest LCC for $80 \%$ or more of households in all regions, except for region 4-warm, where this fraction is about $65 \%$. Option 5 is the second most cost-effective technology. Option 5 is attractive because it uses the power-vent water-heater technology, which already has about $2 \%$ market share.

The national impact analysis shows that both options 5 and 6 have significant potential national energy savings and economic benefits over the 2010 to 2030 period. In particular, option 6 shows very large NPV greater than $\$ 8$ billion due to lower installation costs and higher operating cost savings. Together these more than offset the higher consumer price for the equipment.

Presently, in the new construction market, the choice of furnace and water-heater type is primarily driven by



Fig. 10 NES and NPV results first cost considerations and limited availability of power-vent and condensing storage-tank water heaters. This study suggests that homebuyers in most of the US would benefit from the installation of higher efficiency space and water-heating technologies. It also shows that important benefits may be overlooked when policy analysts evaluate the impact of space and water-heating equipment separately.

The economic results indicate that significant energy savings and consumer benefits may result from large-scale introduction of condensing or powervent water heaters combined with condensing furnaces in US residential new construction.

\section{Future work}

The study was limited by factors that could be addressed in future research. Some of the potential future directions are as follows:

- Broaden the study to cover replacement situations as well as other residential building types (i.e., multifamily and mobile home).

- Broaden the scope to include gas tankless water heaters, variable-fire condensing tankless combined space/water heaters, solar water heaters, combined solar space/water heater, electric water heaters and furnaces, which include heat pump designs, and combination appliances. ${ }^{18}$

Acknowledgments The authors would like to thank Steven Meyers (LBNL), Jim Lutz (LBNL), and Lisa Thompson (LBNL) for providing valuable inputs and reviewing the paper.

Open Access This article is distributed under the terms of the Creative Commons Attribution Noncommercial License which permits any noncommercial use, distribution, and reproduction in any medium, provided the original author(s) and source are credited.

\section{Appendix 1: Energy prices}

The energy use of furnaces and to a lesser extent water heaters varies by month. In general, US monthly energy prices also vary significantly by month. To more accurately capture the annual energy cost used by the

\footnotetext{
${ }^{18}$ Shipments of tankless water heaters are increasing significantly and are projected to be around $25 \%$ of the gas water heating market by 2015. DOE also projects a larger market for heat pump water heaters (US Department of Energy 2009b)
} 
Fig. 11 Natural gas price forecast for 2010

Fig. 12 Natural gas price forecast from 2010 to 2030

Fig. 13 Total installed price by option box plot

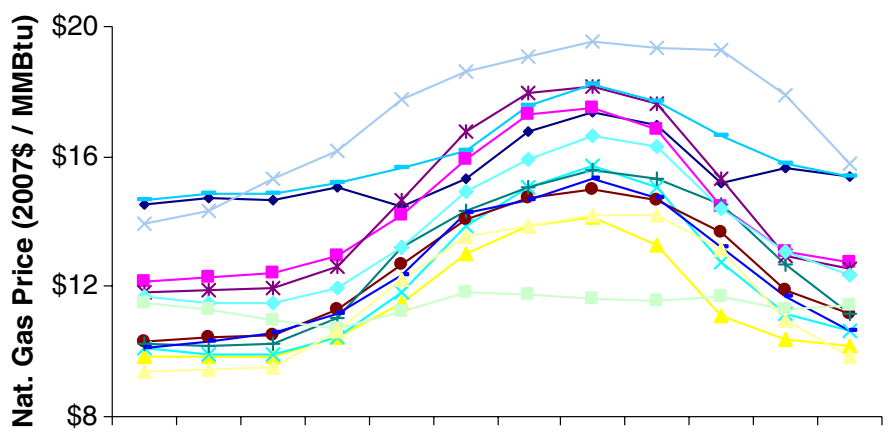

$\longrightarrow$ New England

-C Middle Atlantic

East North Central

West North Central

* South Altantic

- East South Central

West South Central

Mountain

- Pacific

New York

California

Texas

Jan Feb Mar Apr May Jun Jul Aug Sep Oct Nov Dec

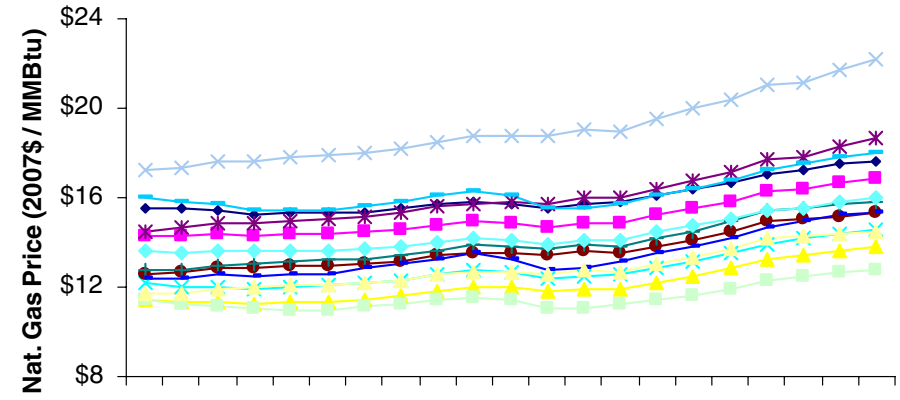

$\longrightarrow$ New England

$\longrightarrow$ - Middle Atlantic

East North Central $\times$ West North Central

$\rightarrow$ South Altantic

$\rightarrow$ East South Central

1 West South Central

Mountain

Pacific

New York

California

Texas

Florida
Hot Water Use Ranges

Average; Median; Box 25\%-75\%; Whisker: 5\%-95\%




Fig. 14 Household heating load by region box plot
Household Heating Load Ranges

Average; Median; Box 25\%-75\%; Whisker: 5\%-95\%
- median

$\square$ Average

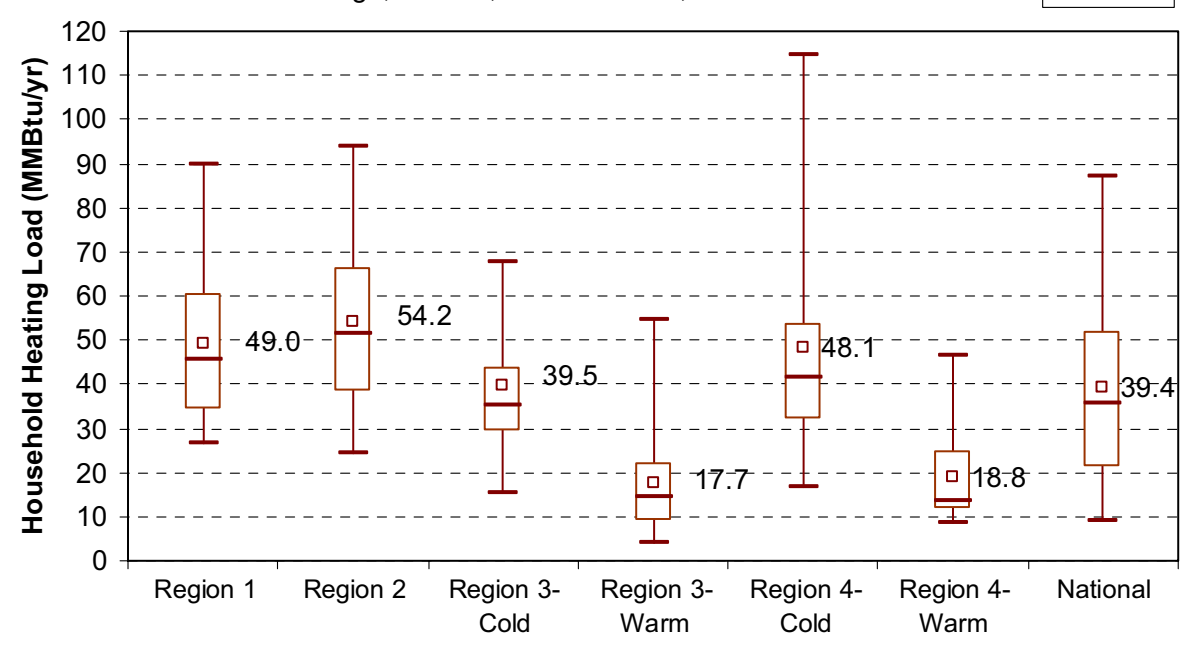

households, this analysis uses regional monthly energy prices instead of annual average energy prices.

The regional monthly energy prices are derived from historical monthly energy prices (US Department of Energy 2005, 2006a, b; US Department of Commerce 2005) and projected into the future using AEO 2009 annual regional energy price projections (US Department of Energy 2009b). As an example, Fig. 11 shows the monthly natural gas price forecast for 2010 for the nine Census Divisions and four large states. Using monthly prices results in lower operating costs, because most consumption occurs in the winter when the natural gas prices are lower compared to the average annual prices.

Figure 12 shows annual trends (based on AEO 2009 projections) for all Census Division and four large states for the period (2010-2030).

\section{Appendix 2: Distribution of results}

The outcome of the LCC analysis is a distribution of values from a sample size of 10,000 households. The following charts (Figs. 13, 14, 15, 16, and 17) show
Fig. 15 Hot water use by region box plot
Hot Water Use Ranges

Average; Median; Box 25\%-75\%; Whisker: 5\%-95\%
- median $\square$ Average

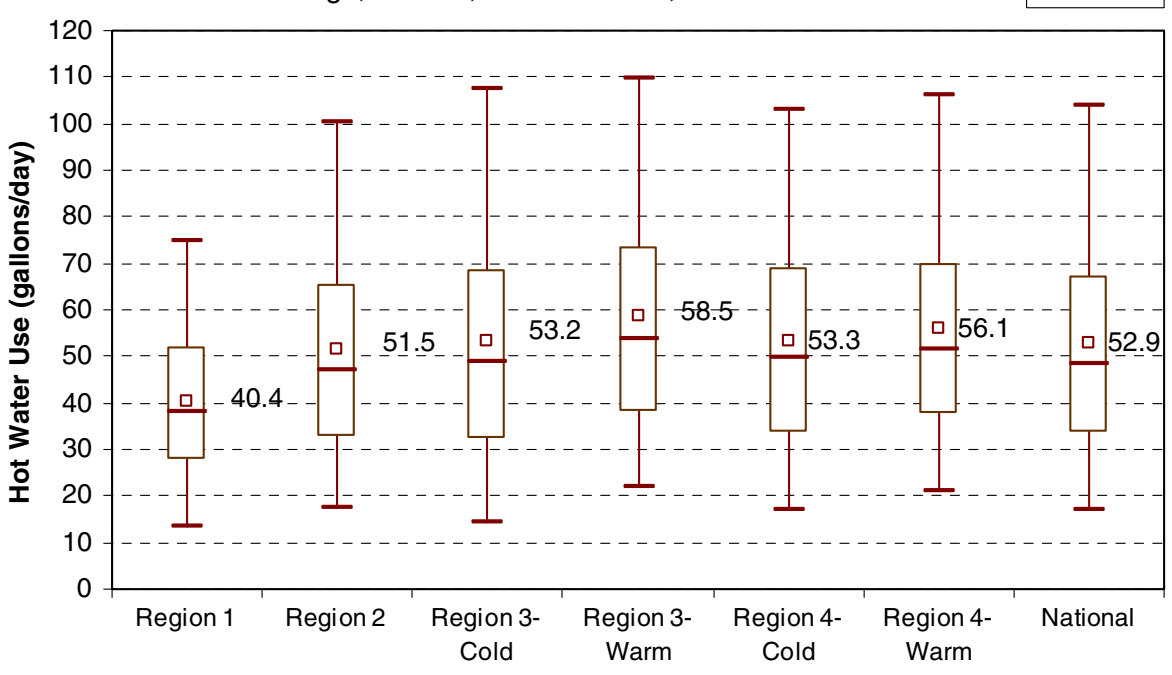


Fig. 16 Total operating cost by option box plot
Total Operating Cost Ranges Average; Median; Box 25\%-75\%; Whisker: 5\%-95\%

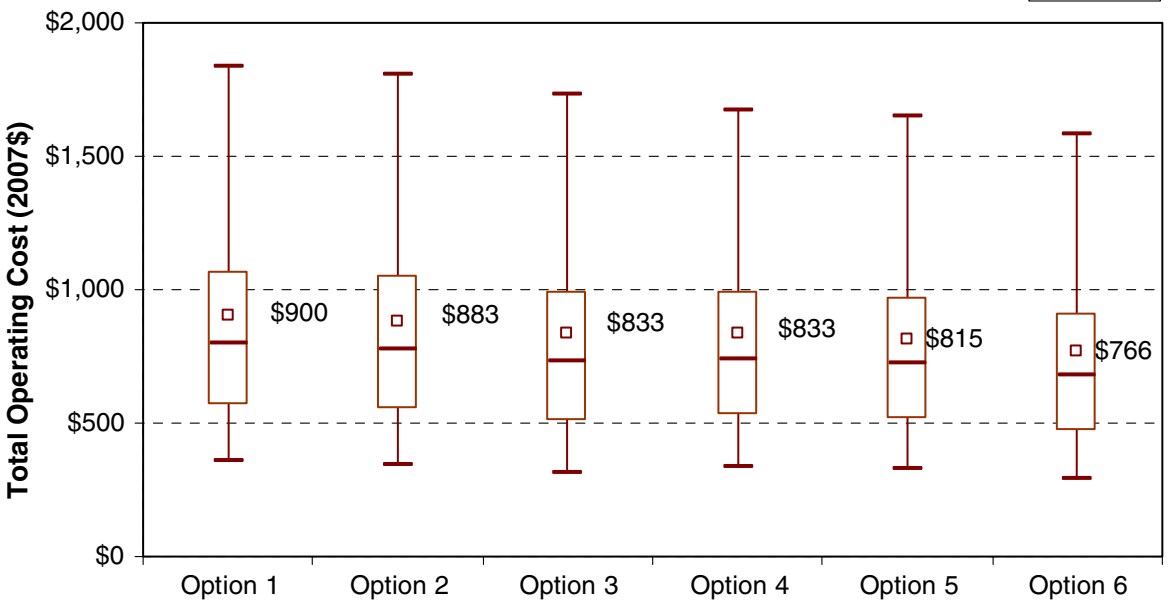

the resulting distributions for the total installed cost, total operating cost and the LCC savings (by option), and for the house heating load and hot water use (regionally and nationally).

\section{Appendix 3: Energy use calculations}

This appendix offers an overview of the equations used to calculate energy use for gas water heaters and gas furnaces (Lutz et al. 1999, 2004).

The Water Heater Analysis Model (WHAM) method (Lutz et al. 1999) is used to derive the average daily water-heater energy consumption $\left(Q_{\text {in }}\right)$ :

$$
\begin{aligned}
Q_{\text {in }}= & \frac{\operatorname{vol} \times \operatorname{den} \times C_{\mathrm{P}} \times\left(T_{\text {tank }}-T_{\text {in }}\right)}{\mathrm{RE}} \\
& \times\left(1-\frac{\mathrm{UA} \times\left(T_{\text {tank }}-T_{\mathrm{amb}}\right)}{P_{\text {on }}}\right)+24 \times \mathrm{UA} \\
& \times\left(T_{\text {tank }}-T_{\mathrm{amb}}\right)
\end{aligned}
$$

where

$C_{\mathrm{p}} \quad$ specific heat of stored water, set constant at $1.000743 \mathrm{Btu} / \mathrm{lb}^{\circ} \mathrm{F}$
Fig. 17 LCC savings by option box plot (negative savings within parentheses)
LCC Savings Ranges

Average; Median; Box 25\%-75\%; Whisker: 5\%-95\%

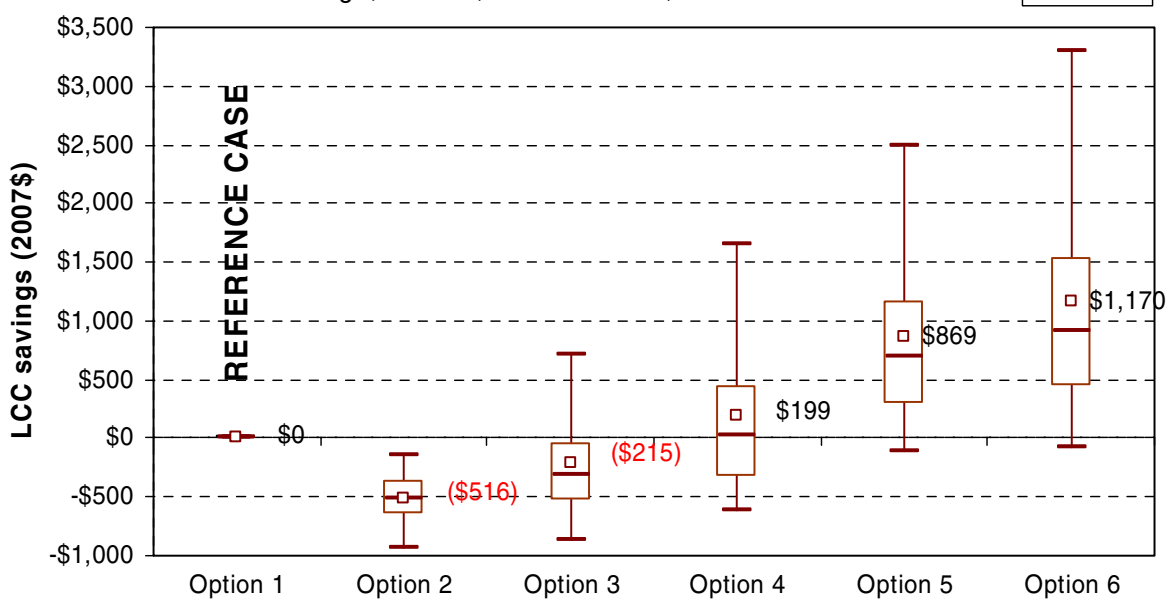


den density of stored water, set constant at $8.29 \mathrm{lb} / \mathrm{gal}$

$P_{\text {on }} \quad$ rated input power, $\mathrm{Btu} / \mathrm{h}$

$Q_{\text {in }} \quad$ total water-heater energy consumption, Btu/day

RE recovery efficiency, \%

$T_{\mathrm{amb}} \quad$ temperature of the air surrounding the water heater, ${ }^{\circ} \mathrm{F}$

$T_{\text {in }} \quad$ inlet water temperature, ${ }^{\circ} \mathrm{F}$

$T_{\text {tank }} \quad$ thermostat set-point temperature, ${ }^{\circ} \mathrm{F}$

vol volume of hot water drawn in $24 \mathrm{~h}$, gal/day

UA standby heat-loss coefficient, Btu/ ${ }^{\circ} \mathrm{F}$

The volume of hot water drawn in $24 \mathrm{~h}$ is determined using a hot water draw model, which uses a set of household characteristics and waterheater performance parameters (US Department of Energy 2009b). WHAM yields total water-heater energy consumption $\left(Q_{\text {in }}\right)$, which is disaggregated into electricity and fuel consumption.

The gas furnace fuel consumption (FuelUse) is calculated using:

FuelUse $=\mathrm{BOH}_{\mathrm{SS}} \times Q_{\mathrm{IN}}$

where

$\mathrm{BOH}_{\mathrm{SS}}$ steady-state burner operating hours (h)

$Q_{\mathrm{IN}} \quad$ input capacity of existing furnace $(\mathrm{kBtu} / \mathrm{h})$

The burner operating hours $\left(\mathrm{BOH}_{\mathrm{SS}}\right)$ for each household are determined using the RECS' household energy use and the performance characteristics of the gas furnace.

\section{References}

Air-Conditioning, Heating, and Refrigeration Institute (2008a). Industry statistical profile: Gas warm air ventral furnaces by AFUE. Air-Conditioning, Heating, and Refrigeration Institute. http://www.ahrinet.org/Content/Furnaces_609. aspx. Accessed 7 August 2008.

Air-Conditioning, Heating, and Refrigeration Institute (2008b). Air-conditioning, heating, and refrigeration shipments data. Air-Conditioning, Heating, and Refrigeration Institute. http://www.ahrinet.org/Content/MonthlyShipmentRe ports_375.aspx. Accessed 7 August 2008.

Ashdown, B. G., Bjornstad, D., Boudreau, G., Lapsa, M., Schexnayder, S., Shumpert, B., et al. (2004). Heat pump water heater technology: Experiences of residential consumers and utilities. Oak Ridge National Laboratory, Report No. ORNL/TM-2004/81. http://www.ornl.gov/ webworks/cppr/ y2005/rpt/120517.pdf. Accessed 7 August 2008.
Energy Star (2008). Energy star residential water heaters: Final criteria analysis. http://www.energystar.gov/index.cfm? $\mathrm{c}=$ new_specs.water_heaters. Accessed 7 August 2008.

Ghent, P., \& Keller, C. (1999). A comprehensive review of market research on solar water heaters. National Renewable Energy Laboratory, Berkeley, CA. Report No. NREL/ SR-550-27123. http://www.nrel.gov/docs/fy00osti/27123. pdf. Accessed 7 August 2008.

Lekov, A., Lutz, J., Liu, X., Dunham-Whitehead, C., \& McMahon, J. (2000). Determining benefits and costs of improved water heater efficiencies. In the proceedings of the 35th Intersociety Energy Conversion Engineering Conference. July 24-28, 2000. Las Vegas, NV. Report No. LBNL-45618.

Lekov, A., Franco, V., Meyers, S., McMahon, J., McNeil, M., \& Lutz, J. (2006). Electricity and natural gas efficiency improvements for residential gas furnaces in the U.S. In the proceedings of the 4th International Conference on Energy Efficiency in Domestic Appliances and Lighting (EEDAL 06). June 21-23, 2006. London, England. Report No. LBNL-59745. http://www-library.lbl.gov/docs/LBNL/ 597/45/PDF/LBNL-59745.pdf. Accessed 7 August 2008.

Lutz, J., Whitehead, C., Lekov, A., Rosenquist, G., \& Winiarski, D. (1999). WHAM: Simplified tool for calculating water heater energy use. ASHRAE Transactions, 105(2), 1005-1015.

Lutz, J. D., Liu, X., Lekov, A., Dunham-Whitehead, C., \& McMahon, J. (2000). A Monte Carlo approach to the calculation of energy consumption for residential gas-fired water heaters. In the proceedings of the American Society of Heating, Refrigeration, and Air-Conditioning Engineers. June 24-28, 2000. Minneapolis, MN.

Lutz, J., Dunham-Whitehead, C., Lekov, A., \& McMahon, J. (2004). Modeling energy consumption of residential furnaces and boilers in U.S. homes. Lawrence Berkeley National Laboratory, Report No LBNL-53924. http:// repositories.cdlib.org/cgi/viewcontent.cgi?article $=2392 \&$ context=lbnl. Accessed 7 August 2008.

US Department of Commerce-Bureau of the Census (2005). American housing survey for the United States in 2005. http://www.census.gov/hhes/www/ahs.html. Accessed 7 August 2008.

US Department of Commerce-Bureau of the Census (2006). Population estimates. http://www.census.gov/popest/esti mates.php. Accessed 7 August 2008.

US Department of Commerce-Bureau of the Census (2008). Characteristics of new housing. http://www.census.gov/ const/www/charindex.html. Accessed 7 August 2008.

US Department of Commerce-Bureau of the Census (2009). Census regions and divsions of the United States. http:// www.census.gov/geo/www/us_regdiv.pdf. Accessed 8 January 2009.

US Department of Energy (2001). Residential energy consumption survey: household energy consumption and expenditures 2001. http://www.eia.doe.gov/emeu/recs/recs2001/ publicuse2001.html. Accessed 18 May 2005.

US Department of Energy (2005). 2005 State energy consumption, price, and expenditure estimates (SEDS). Energy Information Administration. http://www.eia.doe.gov/emeu/ states/_seds.html. Accessed 7 August 2008.

US Department of Energy (2006a). Natural gas navigator. Energy Information Administration. http://tonto.eia.doe. 
gov/dnav/ng/ng_pri_sum_dcu_nus_m.htm. Accessed 7 August 2008.

US Department of Energy (2006b). Form EIA-861: Annual electric utility data. Energy Information Administration. http://www.eia.doe.gov/cneaf/electricity/page/eia861.html. Accessed 7 August 2008.

US Department of Energy (2007). Technical support document: energy efficiency standards for consumer products: Residential furnaces and boilers. Energy Information Administration, Washington, DC. http:/www1.eere.energy.gov/ buildings/appliance_standards/residential/fb_tsd_0907. html. Accessed 7 August 2008.

US Department of Energy (2008). Annual energy outlook 2008 with projections to 2030. Energy Information Administra- tion, Washington, DC. Report No. DOE/EIA-0383(2008). http://www.eia.doe.gov/oiaf/aeo/. Accessed 7 August 2008.

US Department of Energy (2009a). Annual energy outlook 2009 with projections to 2030 Early Release. Energy Information Administration, Washington, DC. Report No. DOE/EIA-0383(2009). http://www.eia.doe.gov/oiaf/aeo/. Accessed 7 January 2009.

US Department of Energy (2009b). Preliminary technical support document: energy efficiency standards for consumer products: heating products. Energy Information Administration, Washington, DC. http://www1.eere.ener gy.gov/buildings/appliance_standards/residential/water pool_heaters_prelim_tsd.html. Accessed 7 January 2009. 